\title{
THE EFFECT OF RARE EARTH ELEMENTS ON Cr PRECIPITATIONS IN A Cu-0.8WT\%Cr ALLOY
}

\author{
GeWANG SHUAI ${ }^{1}$, Meng ZHANG ${ }^{1}$ AND YONGLi YAN ${ }^{2}$ \\ ${ }^{1}$ School of Materials Science and Engineering, Nanchang University, 330047 Nanchang, China, ${ }^{2}$ Department of \\ Basic Courses, Northeastern University at Qinhuangdao, 066000 Qinhuangdao, China \\ e-mails: shuaigw@126.com, zhhmeng@ncu.edu.cn, qhdyyl@126.com \\ (Accepted 21 May, 2004)
}

\begin{abstract}
The microstructural evolution of Cu-based alloys during aging was studied using a quantitative metallographic method. Samples were cut from ingots of $\mathrm{Cu}-0.8 \mathrm{wt} \% \mathrm{Cr}$ and $\mathrm{Cu}-0.8 \mathrm{wt} \% \mathrm{Cr}-\mathrm{RE}$ alloys. These were solution treated at $1000{ }^{\circ} \mathrm{C}$ for $1.5 \mathrm{~h}$ and subsequently quenched in water, then separately aged at $480{ }^{\circ} \mathrm{C}$ for different durations. The microstructures were observed by optical microscope, and the characteristic geometric parameters of precipitated $\mathrm{Cr}$ phase, including volume fraction $\mathrm{V}_{\mathrm{V}}$, face density $\mathrm{N}_{\mathrm{A}}$, mean diameter and roundness, were measured. These data provided more details about the process of aging. The results showed that precipitation of $\mathrm{Cr}$ phase occurred in the form of particles during aging. Rare earth elements promoted the precipitation of $\mathrm{Cr}$ phase and dispersed $\mathrm{Cr}$ particles. The phenomenon of overaging came earlier in $\mathrm{Cu}-\mathrm{Cr}-\mathrm{RE}$ than in $\mathrm{Cu}-\mathrm{Cr}$. In the present work, the optimal aging time at $480{ }^{\circ} \mathrm{C}$ was $2 \mathrm{hrs}$ for the $\mathrm{Cu}-0.8 \mathrm{wt} \% \mathrm{Cr}-\mathrm{RE}$ alloy and 3 hours for the $\mathrm{Cu}-0.8 \mathrm{wt} \% \mathrm{Cr}$ alloy.
\end{abstract}

Keywords: CuCrRE alloy, precipitation, quantitative metallographic analysis.

\section{INTRODUCTION}

Cu-based alloys have many important applications because of their high strength and excellent conductivity. Many methods of alloy preparation have been developed to improve strength, such as aginghardening, rapid solidification, solid solution hardening and mechanical alloying (Morris and Morris, 1989; Batawi et al., 1990; Szablewski and Kuznicka, 1991; Lopez et al., 1997; Jin and Adachi, 1998; Liu et al., 2000). Cu-Cr alloym, as a typical age-hardened alloy, can be strengthened by precipitation of $\mathrm{Cr}$ phase in a copper matrix without impairing its good electrical and thermal conductivities. The morphology, size and distribution of the precipitated $\mathrm{Cr}$ phase have a significant influence on the ultimate properties of the $\mathrm{Cu}-\mathrm{Cr}$ alloy. It has been a topic of great interest of how to control the process of precipitation of $\mathrm{Cr}$ phase (Tang et al., 1985). Previous research showed that the $\mathrm{Cu}-\mathrm{Cr}$ alloy is very sensitive to aging temperature and aging time and easily inclined to overaging under an unsuitable heat treatment program. It also has been discussed that a small addition of other elements to a $\mathrm{Cu}-\mathrm{Cr}$ alloy can improve its properties (Fernee et al., 2001). We have focused on the addition of rare earth elements to the $\mathrm{Cu}-\mathrm{Cr}$ alloy. $\mathrm{RE}$ additives have been applied in many alloys and showed good effects of cleaning the matrix and microalloying (Du, 1996; Tan et al., 1999), but little applied research of $\mathrm{RE}$ elements in $\mathrm{Cu}-\mathrm{Cr}$ alloys has been carried out.

It is well known that the distribution of the secondary phase in the matrix has a very important influence upon the properties of materials. Some previous research has described methods for the spatial distribution of the secondary phase and the effects on properties of materials including ferrous metals and composites (Horalek et al., 1988; 1989a,b; Liu and Yu, 1996; Wang et al., 2000; Popa and Chaix, 2002). There were few reports dealing with the distribution of secondary precipitation in $\mathrm{Cu}-\mathrm{Cr}-$ $\mathrm{RE}$ alloys after being aged by using quantitative metallographic analysis. In this paper, characteristic geometric parameters of precipitated $\mathrm{Cr}$ particles in $\mathrm{Cu}-\mathrm{Cr}$ and $\mathrm{Cu}-\mathrm{Cr}-\mathrm{RE}$ alloys have been measured using quantitative metallographic method. The results provide valuable information for choosing the optimal procedure for aging treatment and to obtain a suitable $\mathrm{Cu}-\mathrm{Cr}$ alloy with better properties. 


\section{MATERIAL AND METHODS}

\section{SAMPLE PREPARATION}

$\mathrm{Cu}-0.8 \mathrm{wt} \% \mathrm{Cr}-\mathrm{RE}$ alloy was prepared by vacuum induction melting from electrolytic copper, $\mathrm{Cu}$ $4 \mathrm{wt} \% \mathrm{Cr}$ and $\mathrm{Cu}-10 \mathrm{wt} \% \mathrm{RE}$ alloys. A Cu- $0.8 \mathrm{wt} \% \mathrm{Cr}$ alloy was also prepared for comparison. Samples cut from the cross section of ingots were solution treated at $1000{ }^{\circ} \mathrm{C}$ for $1.5 \mathrm{~h}$ followed by water quenching. The solution-treated samples were separately aged at $480{ }^{\circ} \mathrm{C}$ for $1 \mathrm{~h}, 2 \mathrm{~h}, 3 \mathrm{~h}$ and $4 \mathrm{~h}$. The specimens for observation by optical microscope were polished and etched in a solution of $\mathrm{FeCl}_{3}, \mathrm{HCl}$ and absolute alcohol. In order to examine the crystal structures of phases in the samples, X-Ray diffraction was carried out by $\mathrm{D} / \mathrm{max}-3 \mathrm{~B}$ diffractometer.

\section{QUANTITATIVE METALLOGRAPHIC ANALYSIS}

The microstructures were observed with a MeF3 optical microscope and objective with $50 \times$ magnification equipped with a digital camera having a resolution of $800 \times 1000$ pixels. Quantitative metallographic analysis was carried out using ImagePro Plus (IPP) software for image analysis. For our work, IPP was used for the preparation of taskoriented functions, based on the principle of stereology and quantitative metallography, used to perform the measurements of characteristic geometric parameters. In order to assure appropriate accuracy of the results, 30 fields randomly selected in each sample were analyzed. Due to the limit of resolution of the optical microscope, the parameter of area identifying $S_{\min }$ was set to $1 \mu^{2}$, so that only particles with an area larger than $1 \mu^{2}$ were measured and noise was almost eliminated.

\section{RESULTS}

The scans of X-Ray diffraction showed both facecentered cubic (fcc) $\mathrm{Cu}$ and body-centered cubic (bcc) $\mathrm{Cr}$ in all of the samples. After aging treatment, the intensity of diffraction peaks of $\mathrm{Cr}$ became larger. The results suggested that precipitation of $\mathrm{Cr}$ phase occurred during aging. The microscopy observation showed that the precipitated $\mathrm{Cr}$ phase was in the form of particles distributed in the copper matrix. Scans carried out on the peaks of all samples did not show evidence of additional peaks for RE, because RE content was too low.
Optical microscopic examination showed that the microstructures of both alloys were dendritic, with some $\mathrm{Cr}$ particles homogeneously distributed in the material prior to solution treatments. We selected four figures (Figs. 1-4) to show the microstructures of $\mathrm{Cu}-0.8 \mathrm{wt} \% \mathrm{Cr}$ and $\mathrm{Cu}-0.8 \mathrm{wt} \% \mathrm{Cr}-\mathrm{RE}$ alloys before and after aging. After solution treatment, the number of $\mathrm{Cr}$ particles was lower, as shown in Figs. 1 and 3. There is no evident difference between the two alloys.

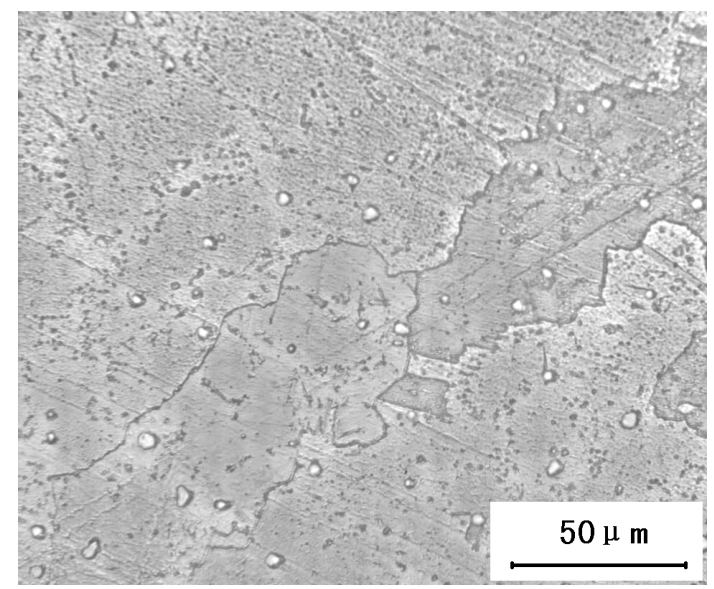

Fig. 1. Microstructure of $\mathrm{Cu}-0.8 \mathrm{Cr}$ after $1000{ }^{\circ} \mathrm{C} \times 1.5 \mathrm{~h}$ solution heat treatment.

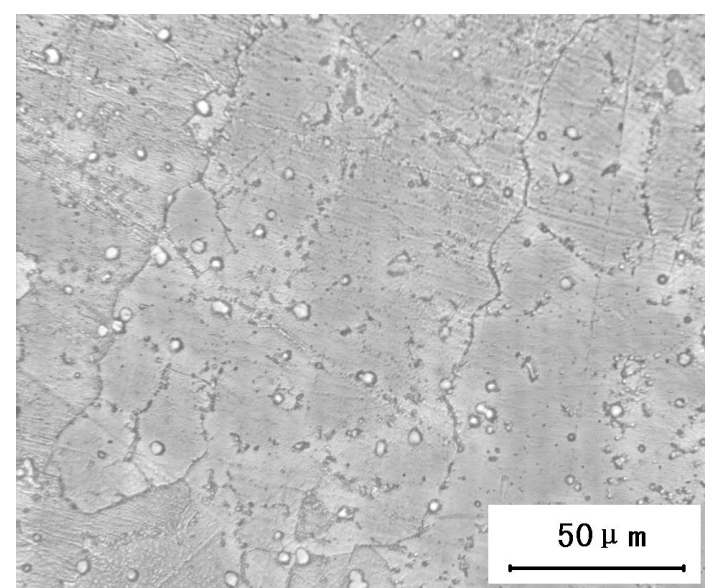

Fig. 2. Microstructure of $\mathrm{Cu}-0.8 \mathrm{Cr}$ after $480^{\circ} \mathrm{C} \times 2 \mathrm{~h}$ aging treatment.

After aging at $480{ }^{\circ} \mathrm{C}$ more and more particles appeared in the matrices and the number increased with increasing aging time in both $\mathrm{Cu}-\mathrm{Cr}$ and $\mathrm{Cu}-\mathrm{Cr}$ RE alloys. Figs. 2 and 4 showed the typical microstructures of $\mathrm{Cu}-\mathrm{Cr}$ and $\mathrm{Cu}-\mathrm{Cr}-\mathrm{RE}$ alloys after being aged at $480{ }^{\circ} \mathrm{C}$ for $2 \mathrm{~h}$. It indicated that $\mathrm{Cr}$ precipitation occurred. There are more particles in Fig. 4 than in Fig. 2, and the particles in Fig. 4 are much finer. 
Curves in Figs. 5-8 show the variations in volume fraction $\mathrm{V}_{\mathrm{V}}$, face density $\mathrm{N}_{\mathrm{A}}$, mean diameter and roundness of $\mathrm{Cr}$ particles with aging time for the two alloys.

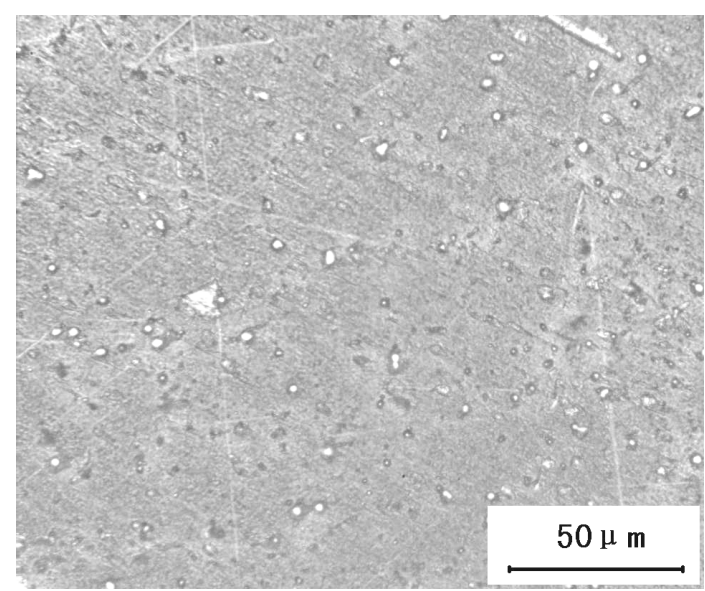

Fig. 3. Microstructure of $\mathrm{Cu}-0.8 \mathrm{Cr}-\mathrm{RE}$ after $1000^{\circ} \mathrm{C}$ $\times 1.5$ h-solution heat treatment.

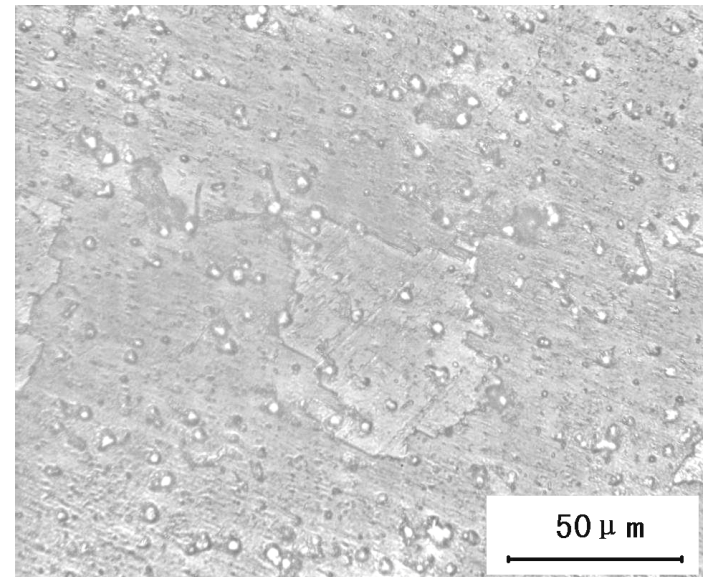

Fig. 4. Microstructure of Cu-0.8Cr-RE after $480^{\circ} \mathrm{C}$ $\times 2 h$-aging treatment.

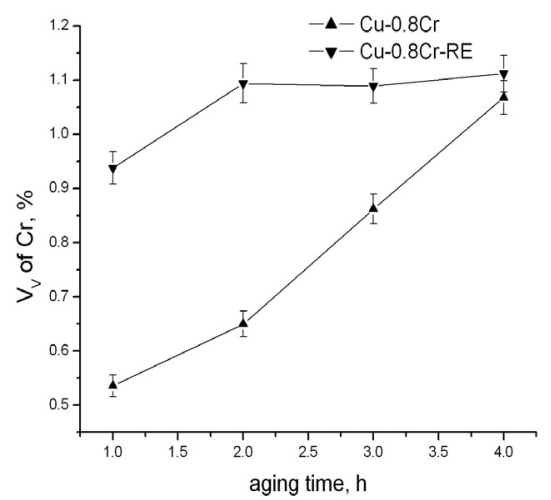

Fig. 5. Volume fraction $V_{v}$ of $\mathrm{Cr}$ as a function of aging time.

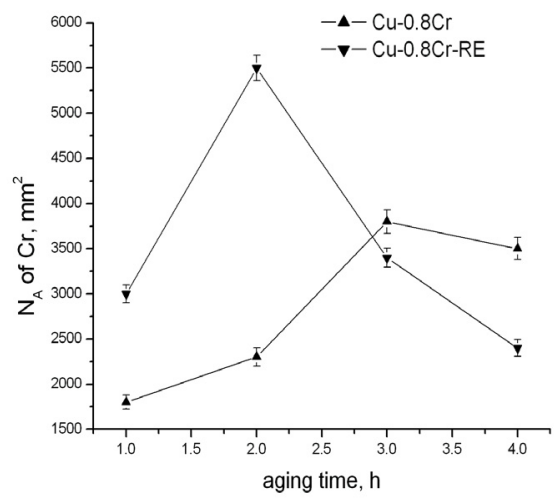

Fig. 6. Face density $N_{A}$ of $\mathrm{Cr}$ as a function of aging time.

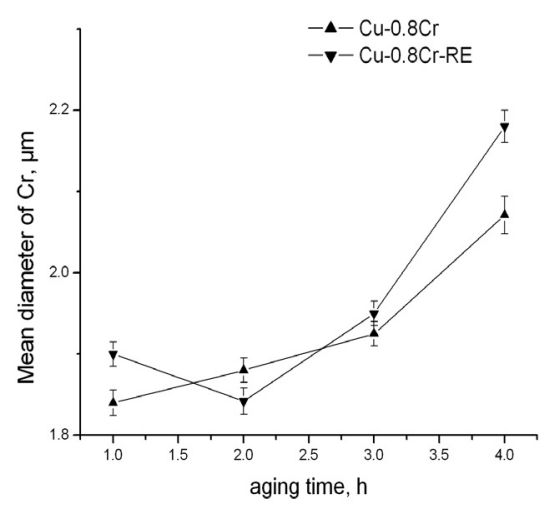

Fig. 7. Mean diameter of $\mathrm{Cr}$ as a function of aging time.

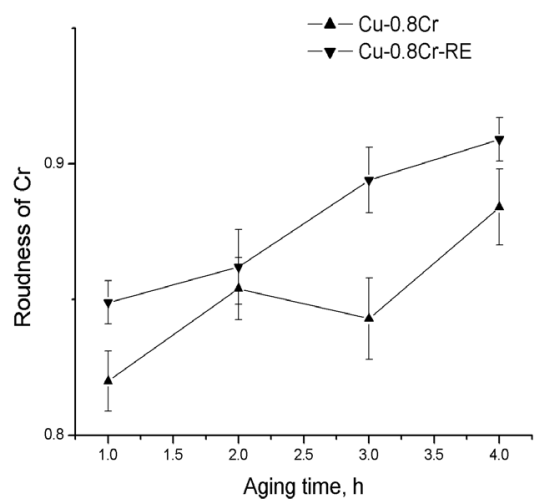

Fig. 8. Roundness of $\mathrm{Cr}$ as a function of aging time.

$\mathrm{V}_{\mathrm{V}}$ of $\mathrm{Cr}$ particles in two sample alloys increased with increasing aging time (as shown in Fig. 5). In the $\mathrm{Cu}-\mathrm{Cr}-\mathrm{RE}$ alloy, it reached the maximum value after aging for $2 \mathrm{hrs}$, then tended to be stable. In the $\mathrm{Cu}-\mathrm{Cr}$ alloy, it increased as a function of aging time and approached the value of $\mathrm{Cu}-\mathrm{Cr}$-RE after aging for 4 hrs. 
$\mathrm{N}_{\mathrm{A}}$ of $\mathrm{Cr}$ particles in these samples increased at the beginning and then decreased after reaching the maximum value, as shown in Fig. 6. The peak value of $\mathrm{N}_{\mathrm{A}}$ in the $\mathrm{Cu}-\mathrm{Cr}-\mathrm{RE}$ alloy was higher and appeared earlier than in the $\mathrm{Cu}-\mathrm{Cr}$ alloy. Table. 1 gives the rates of increase and decrease of $\mathrm{N}_{\mathrm{A}}$ of $\mathrm{Cr}$ particles in these two alloys. It shows that the rates changed faster in $\mathrm{Cu}-\mathrm{Cr}-\mathrm{RE}$ than in $\mathrm{Cu}-\mathrm{Cr}$.

Table 1. Rates of increase and decrease of $N_{A}$ of chromium particles for two alloys.

\begin{tabular}{lcc}
\hline & $\mathrm{Cu}-0.8 \mathrm{wt} \% \mathrm{Cr}$ & $\mathrm{Cu}-0.8 \mathrm{wt} \% \mathrm{Cr}-\mathrm{RE}$ \\
\hline $\begin{array}{l}\text { rate of } \\
\text { increase, } / \mathrm{mm}^{2} \cdot \mathrm{h}\end{array}$ & 1000 & 2500 \\
$\begin{array}{l}\text { rate of } \\
\text { decrease, } / \mathrm{mm}^{2} \cdot \mathrm{h}\end{array}$ & 500 & 1550 \\
\hline
\end{tabular}

From Fig. 7 it can be seen that the mean diameter of chromium particles increased with increasing aging time and the size of particles in $\mathrm{Cu}-\mathrm{Cr}-\mathrm{RE}$ was larger than in the $\mathrm{Cu}-\mathrm{Cr}$ alloy except at $2 \mathrm{~h}$. The rate of coarsening of precipitated $\mathrm{Cr}$ particles in $\mathrm{Cu}-\mathrm{Cr}$ $\mathrm{RE}(0.093 \mu \mathrm{m} / \mathrm{h})$ was higher than that in $\mathrm{Cu}-\mathrm{Cr}$ $(0.077 \mu \mathrm{m} / \mathrm{h})$.

The roundness we measured is defined by the following formula:

$$
\text { Roundness }=\frac{4 \cdot \mathrm{Pi} \cdot \text { area }}{\text { Perimeter }^{2}}
$$

where perimeter is the length of the object's outline, and area is the surface of each object. Circular objects will have a roundness $=1$; other shapes will have a roundness $<1$.

The variations of roundness of chromium particles are presented in Fig. 8. Roundness increased with increasing aging time in both alloys in a general way, except that it decreased abnormally at $3 \mathrm{~h}$ in the $\mathrm{Cu}-\mathrm{Cr}$ alloy. The value of roundness in the $\mathrm{Cu}-\mathrm{Cr}$ alloy was smaller than that in $\mathrm{Cu}-\mathrm{Cr}-\mathrm{RE}$.

\section{DISCUSSION}

From Figs. 1 and 3 it is obvious that solution treatment did not dissolve all of the Cr particles in the copper matrices. The maximum equilibrium solubility of chromium in copper is only about $0.8 \mathrm{wt} \%$ even at $1070{ }^{\circ} \mathrm{C}$ (Tenwick and Davies, 1988), which is higher than the temperature of solution treated in this paper. $\mathrm{Cr}$ particles existed in all samples. They could be divided into two groups: finer ones and coarser ones. The finer ones were the result of solid-state precipitation during aging, while the coarser ones were created directly from melting during casting. After solution treatment, these unresolved $\mathrm{Cr}$ particles did not affect the subsequent quantitative analysis because they kept almost stable during the aging processes.

Figs. 2 and 4 show that the two alloys behaved differently during aging. Comparing the micrographic image of the $\mathrm{Cu}-\mathrm{Cr}-\mathrm{RE}$ and $\mathrm{Cu}-\mathrm{Cr}$ alloys, we could find no evident difference of precipitated $\mathrm{Cr}$ particles in these two alloys. However, the results of quantitative analysis showed more details.

Fig. 5 shows that $\mathrm{V}_{\mathrm{V}}$ of $\mathrm{Cr}$ phase was about $1.094 \%$ in $\mathrm{Cu}-\mathrm{Cr}-\mathrm{RE}$ after being aged for $2 \mathrm{~h}$ and about $1.068 \%$ in $\mathrm{Cu}-\mathrm{Cr}$ after aging for $4 \mathrm{~h}$. It is obvious that rare earth elements promoted the process of precipitation. Also, these results suggest that the $\mathrm{Cr}$ phase had precipitated completely after aging.

According to the theory of precipitation hardening (Porter, 1981), a large number of nuclei appeared in the matrices due to the severe driving force at the early aging stage and the size of precipitated particles was small. Then they grew with time and the spacing between the precipitates became large. The processes of precipitating and coarsening of the secondary phase were accompanied by the process of longdistance diffusing of secondary phase atoms. These evolutions of microstructures during the aging process would lead to the conclusion that the hardness of material increased at first and then decreased. Specimens aged beyond peak hardness were referred to as overaged. Comparing these curves in Figs. 5-7, RE elements speeded the processes of aging including nuclei and growth of precipitated particles.

It should be further noted that the phenomenon of overaging came earlier in $\mathrm{Cu}-\mathrm{Cr}-\mathrm{RE}$ than in $\mathrm{Cu}-\mathrm{Cr}$. It suggests that although we can get a finer precipitate distribution in the $\mathrm{Cu}-\mathrm{Cr}-\mathrm{RE}$ alloy, we should perform aging operations on this kind of alloy much more carefully.

As we know, in the early stage of aging, the morphology of the second phase is usually plates and pillars with bad roundness because of the influence of strain energy. With the coarsening of the second phase, the morphology of the precipitated phase becomes spheres with good roundness in order to decrease the total interface energy. Therefore, the two factors of precipitating and coarsening have opposite influences on roundness. Roundness as a statistical parameter is determined by the dominant factor. 


\section{CONCLUSION}

A systematic study of microstructure evolution by using a quantitative metallographic method has enabled the determination of the characteristics of precipitated $\mathrm{Cr}$ phase in $\mathrm{Cu}-\mathrm{Cr}$ and $\mathrm{Cu}-\mathrm{Cr}-\mathrm{RE}$ alloys. The data of volume fraction $\mathrm{V}_{\mathrm{V}}$, face density $\mathrm{N}_{\mathrm{A}}$, mean diameter and roundness of $\mathrm{Cr}$ particles measured from microscopy morphologies can provide more details about the processes of aging. The main effect of rare earth additives is that REs promote the processes of aging including nuclei and the growth of precipitate particles. The phenomenon of overaging comes earlier in $\mathrm{Cu}-\mathrm{Cr}-\mathrm{RE}$ than in $\mathrm{Cu}-\mathrm{CR}$. Consideration must be given to the effects of rare earth elements when deciding on the best aging operation in practice. In the present work, the optimal aging time at $480{ }^{\circ} \mathrm{C}$ is 2 hours for $\mathrm{Cu}-0.8 \mathrm{wt} \% \mathrm{Cr}-\mathrm{RE}$ alloy and $3 \mathrm{hrs}$ for $\mathrm{Cu}-0.8 \mathrm{wt} \% \mathrm{Cr}$ alloy.

\section{ACKNOWLEDGEMENTS}

This work was supported by the Foundation for University Key Teacher by the Ministry of Education of China under Contract No.GG-430-11902-1010 and the Natural Science Foundation of Jiangxi, China under Contract No.0050022.

The preliminary form of this paper was originally presented at the $\mathrm{XI}^{\text {th }}$ International Congress for Stereology-Beijing Conference, Beijing, China, 4-8 November 2003.

\section{REFERENCES}

Batawi E, Morris DG, Morris MA (1990). Effects of small alloying additions on behavior of rapidly solidified Cu-Cr alloys. Mater Sci Technol 6:892-9.

$\mathrm{Du} T$ (1996). The effect and mechanism of rare earth elements in metals. Trans Nonferr Met Soc Chin 6(2): 13-8.

Fernee H, Nairn J, Atrens A (2001). Precipitation hardening of Cu-Fe-Cr alloys. J Mater Sci. 36:2721-41.

Horalek V, Benes V, Suchanek V (1988). Stereology of structures with various types of spacing of dispersed spherical particles. Practical Metall 25(12):596-603.

Horalek V, Benes V, Suchanek V (1989). Stereology of structures with various types of spacing of dispersed spherical particles. Practical Metall 26(1): 25-34.

Horalek V, Benes V, Suchanek V (1985). Stereology of structures with various types of spacing of dispersed spherical particles. Practical Metall 26(2):83-90.

Jin H, Adachi K (1998). Ageing characteristics of $\mathrm{Cu}-\mathrm{Cr}$ in-situ composite. J Mater Sci 33:1333-41.

Liu G, Yu H (1996). Stereological characterization of particles contiguity. J Microscopy 181(1):82-7.

Liu P, Kang BX, Cao XG, Huang JL, Gu HC (2000). Strengthening mechanisms in a rapidly solidified and aged Cu-Cr alloy. J Mater Sci 35(6):1691-4.

Lopez F, Reyes J, Campillo B, Aguilar-Sahagun G, JuarezIslas JA (1997). Rapid solidification of copper alloys with high strength and high conductivity. JMEPEG 6:611-4.

Morris MA, Morris DG (1989). Microstructural refinement and associated strength of copper alloys obtained by mechanical alloying. Mater Sci Eng A111:115-27.

Popa AM, Chaix JM (2002). Quantitative image analysis of microstructure evolution during solid state sintering of W-Cu. Image Anal Stereol 21:133-8.

Porter DA (1981). Phase Transformations in Metals and Alloys. Van Nostrand Reinhold Company Ltd.

Szablewski J, Kuznicka B (1991). Electrical properties of rapidly solidified $\mathrm{Cu}-\mathrm{Cr}$ alloys. Mater Sci Technol 7:407-9.

Tan LK, Li Y, Ng SC, Lu L (1999). Effects of rare earth additions on structures and properties of rapidly solidified copper alloys. J Mater Sci Technol 15(2): 169-79.

Tang NY, Taplin DMR, Dunlop GL (1985). Precipitation and aging in high-conductivity $\mathrm{Cu}-\mathrm{Cr}$ alloys with additions of zirconium and magnesium. J Mater Sci Technol 1:270-5.

Tenwick MJ, Davies HA (1988). Enhanced strength in high conductivity copper alloys. Mat Sci Eng 98:543-6.

Wang HY, Shang JL, Liu GQ, Qin XG, Song XY (2000). Overview on description methods for the spatial distribution of the second phase in multi-phase materials. Advan Mech 30(4):558-70. 